University of Michigan Law School

University of Michigan Law School Scholarship Repository

\title{
A Surety's Claim against His Bankrupt Principal under the Present Law
}

\author{
Evans Holbrook \\ University of Michigan Law School
}

Available at: https://repository.law.umich.edu/articles/1154

Follow this and additional works at: https://repository.law.umich.edu/articles

Part of the Bankruptcy Law Commons, and the Legislation Commons

\section{Recommended Citation}

Holbrook, Evans. "A Surety's Claim against His Bankrupt Principal under the Present Law." U. Pa. L. Rev. 60 (1912): 482-97.

This Article is brought to you for free and open access by the Faculty Scholarship at University of Michigan Law School Scholarship Repository. It has been accepted for inclusion in Articles by an authorized administrator of University of Michigan Law School Scholarship Repository. For more information, please contact mlaw.repository@umich.edu. 


\section{A SURETY'S CLAIM AGAINST HIS BANKRUPT PRINCIPAL UNDER THE PRESENT LAW.}

The peculiar three-sided relationship of principal, surety and creditor gives rise to many vexatious questions of law, and one of the most interesting of these vexatious questions is that of the relationship between surety and principal in the case of the latter's bankruptcy. Under such circumstances, the creditor's right is fairly simple; he may prove his debt against the principal, take such dividend as may be declared, and recover the balance of the debt from the surety, his remedy against the latter being expressly saved by Sec. 16 of the present Bankruptcy Act. ${ }^{1}$ But the position of the surety is less clear. Upon becoming a surety, he has acquired a two-sided status of liability and right; he has become liable to pay money to the creditor if the principal defaults; and if he does so pay to the creditor, he has a right to be reimbursed by the principal for the payment so made. In other words, the surety is contingently the debtor of the creditor, and the creditor of the debtor (principal). And this contingent liability and right exist in the surety from the time of making the contract of suretyship. $\mathrm{He}$ is, clearly enough, always liable to pay the debt to the creditor if the prineipal does not, and he is also always the possessor of a right against the principal, namely, the right to be reimbursed for any payment he may have to make on the principal's account. It is the nature of this right that leads to the difficulty of determining the status in bankruptcy of the surety's claim against his bankrupt principal. It is clear that the surety, from the time of making the contract of suretyship, has a potential claim, or contingent possibility of a right, against his principal, but it is equally clear that this claim or right does not become absolute and fixed until the surety has made a payment for his principal. Until this time he has no right of action against his principal, but merely a contingent possibility of a right. The following

"This section is as follows: "The liability of a person who is a codebtor with, or guarantor or in any manner a surety for, a bankrupt shall not be altered by the discharge of such bankrupt."

(482) 
questions naturally arise as to this right to reimbursement: Can the holder of this claim (the surety) join in a petition in involuntary bankruptcy against the principal? Can he prove his claim against the principal's estate? Is his right against the principal barred by the latter's discharge in bankruptcy? Is the surety, by virtue of his inchoate claim, a creditor who may be preferred or defrauded by the bankrupt principal?

Under the Federal Bankruptcy Acts of I84I and 1867, it is clear that the surety's claim for reimbursement by his bankrupt principal was a provable claim against the principal, and that it was therefore barred by the principal's discharge in bankruptcy. ${ }^{2}$ And it is also perfectly clear that such a claim is provable and is discharged under the English Bankruptcy Act, whose provisions for the proof of contingent and uncertain claims go far beyond anything that has been contained in any of the Federal Bankruptcy Acts. ${ }^{3}$ The Federal Bankruptcy Act 508 .

2 Mace v. Wells (1849), 7 How. 272; Hunt v. Taylor (1871), 108 Mass.

Section 5 of the Act of 184I was in part as follows: "all creditors whose debts are not due and payable until a future day, ... all sureties, indorsers, bail, or other persons having uncertain or contingent demands against such bankrupt, shall be permitted to come in and prove such debts or claims under this act, and shall have a right when their debts and claims become absolute to have the same allowed them"; and Section I6 of the Act of I867 was in part as follows: "In all cases of contingent debts and contingent liabilities contracted by the bankrupt, . . . the creditor may make claim therefor and have his claim allowed, with the right to share in the dividends if the contingency shall happen before the order for the final dividend; or he may at any time apply to the court to have the present value of the debt or liability ascertained and liquidated, which shall be done in such manner as the court shall order, and he shall be allowed to prove for the amount so ascertained."

${ }^{8}$ The English Bankruptcy Act of 1883 (46 \& 47 Victoria, c. 52), provides as follows: Section 37(3) ". . . all debts and liabilities, present or future, certain or contingent, to which the debtor is subject at the date of the receiving order, or to which he may become subject before his discharge by reason of any obligation incurred before the date of the receiving order, shall be deemed to be debts provable in bankruptcy" and provides further, in Section 37(8) that "liability" shall include, among other things, "any" obligation or possibility of an obligation to pay money or money's worth on the breach of any express or implied covenant, contract, agreement, or undertaking, whether the breach does or does not occur, or is or is not likely to occur or capable of occurring before the discharge of the debtor." An interesting case under this section is Victor v. Victor, (rgI2) I K. B. 247, where the court held that a wife's claim against her husband, based on a separation agreement in which he undertook to pay her a stated annuity, was provable in the husband's bankruptcy, and was discharged thereby, despite a provision that the agreement was to become void on the parties resuming cohabitation, saying (p. 25I): "Under modern bankruptcy legisla- 
of 1898 , however, differs considerably from the previous statutes, and much doubt has arisen over the precise effect of its provisions as to claims of the nature of a surety's claim for reimbursement. The doubt comes largely from the uncertainty as to the provisions of Secs. $57 \mathrm{i}$ and $63 \mathrm{a}$ (I) and (4) of the Act: the latter section prescribes what claims are provable, as follows :

"a. Debts of the bankrupt which may be proved and allowed against his estate which are (I) a fixed liability, as evidenced by a judgment or an instrument in writing, absolutely owing at the time of the filing of the petition against him, whether then payable or not, with any interest thereon which would have been recoverable at that date or with a rebate of interest upon such as were not then payable and did not bear interest; . . . (4) founded upon an open account, or upon a contract express or implied;"

while the former section contains the statute's only direct reference to the proof of claims of indorsers and other sureties, in the following words:

"Whenever a creditor, whose claim against a bankrupt estate is securéd by the individual undertaking of any person, fails to prove such claim, such person may do so in the creditor's name, and if he discharges such undertaking in whole or in part he shall be subrogated to that extent to the rights of the creditor." "

The question presents itself: Is the surety's claim to a reimbursement "a fixed liability . . . absolutely owing at the time of the filing of the petition" or a debt "founded... upon a contract express or implied," so as to be a provable debt under Sec. 63a (I) and (4); or is the surety's only right under the Act the right to insure a proper proof of the creditor's debt

tion, however difficult it may be to measure the liability incurred by a husband under a separation deed, the liability ceasing when cohabitation is resumed, still it was a liability that had to be estimated, and that if it could be estimated in no other way it must be left to a jury to estimate it."

Such a restult would of course be impossible under the United States Bankruptcy Act of 1898 . See Dunbar v. Dunbar (1903), 190 U. S. 340.

"Section $57 \mathrm{i}$ is amplified as follows by General Order XXI(4): "The claims of persons contingently liable for the bankrupt may be proved in the name of the creditor when known by the party contingently liable. When the name of the creditor is unknown, such claim may be proved in the name of the party contingently liable; but no dividend shall be paid upon such claim, except upon satisfactory proof that it will diminish pro tanto the original debt." 
against the bankrupt principal, and thus reduce, by the amount of any dividend that may be paid, the amount that the surety will eventually have to pay to the creditor? And it is remarkable that the courts have been able to give so many answers and reasons for answers to this question.

In the first place, many courts liave expressed grave doubts as to whether any contingent claims are provable under the Act of I898. It is clear that a landlord's claim for rent accruing after his tenant's bankruptcy is not provable, ${ }^{5}$ nor is a landlord's claim which is based upon a.tenant's contract to indemnify the landlord for any loss of rents that may follow a possible bankruptcy of the tenant. ${ }^{\circ}$ The Circuit Court of Appeals for the Second Circuit in In re Roth \& Appel, ${ }^{7}$ held that the lancllord's claim, considered in either of the above aspects, "was altogether contingent in its nature" and held that the clain could not be proved under Sec. 63a(I) as "a fixed liability as evidenced by ... an instrument in writing, absolutely owing at the time of filing the petition," or under Sec. 63a (4) as "founded upon . . . a contract express or implied," basing its holding on the authority of $I n$ re Swift ${ }^{8}$ and In re Adams and quoting from these cases as follows:

"That part of the present bankruptcy act which describes what debts may be proved does not repeat at all points the words 'owing at the time of the filing of the petition,' but it is impossible to consider it other than as though it did thus repeat them." ${ }^{10}$ "But a creditor cannot prove for an indebtedness arising between the filing of the involuntary petition and adjudication. This appears from the analogy of sections $63 a(1),(2),(3)$, and (5), as applied to the interpretation of clause (4). In clauses (I) and (4), for example, the limit of time must be the same, inasmuch as clause (4) includes clause (I), and, if clause (4) were less limited in point of time, the limit imposed on clause (I) would become nugatory." 11

"In re Ells (1900), 98 Fed. 967 ; In re Arnstein (1899), Ior id. 706; In re Mahler (1900), 105 id. 428; Watson v. Merrill (1905), r36 id. 359, 69 C. C. A. I85; In re Roth \& Appel (I9I0), I8r Fed. 667 , I04 C. C. A. 649.

'In re Ells, supra; In re Roth \& Appel, supra.

' (I910), I8r Fed. 667, 104 C. C. A. 649, at p, 655.

${ }^{2}$ (IgOI), II2 Fed. 315, 50 C. C. A. 264.

${ }^{9}$ (I904), r30 Fed. 38r.

${ }^{10} \mathrm{II} 2$ Fed. 315 , at p. 321 , 50 C. C. A. 264 , at p. 270.

${ }^{11}$ I30 Fed. 38r, at p. 382 . 
And the Supreme Court, in Dunbar v. Dunbar, ${ }^{12}$ while conceding that the Act of 1898 provides for discharging some classes of contingent demands or claims; holds that a husband's undertaking to pay an annuity to his divorced wife during her life or widowhood is not a provable debt against his estate in bankruptcy and is not barred by the discharge. The court refers to the "extraordinarily broad language" of the English Act, some decisions under which were cited in argument, ${ }^{13}$ and says:

“

no such broad language is found in our bankruptcy act of 1898 . . . . We do not think that by the use of the langauge in section $63 \mathrm{a}$ it was intended to permit proof of contingent debts or liabilities or demands the valuation or estimation of which it was substantially impossible to prove."

Under the view expressed in these decisions, it is not difficult to justify the view of the Massachusetts court in deciding baldly that no contingent claims are provable under the present bankruptcy act. ${ }^{14}$

On the other hand, there is abundant authority for the proposition that certain kinds of contingent claims are provable; some courts hold that Sec. 63a(4) includes contingent contract claims, because they are "founded upon . . . a contract express or implied," disregarding the interpretation of that clause in the Swift and Adams cases (supra) and taking the view that any claim founded on an express or implied contract may be proved $;^{\mathbf{1 5}}$ other cases hold merely that the contingent claims of sureties and indorsers are provable, and that the provability of these rests upon the provision of Sec. 57 i. $^{16}$ The validity of

II (1903), I90 U. S. 340.

${ }^{13}$ This provision referred to by the Supreme Court is practically the same as that of the present English act, quoted in note 3 above.

${ }^{14}$ Morgan v. Wordell (I9OI), I78 Mass. 350; followed in Goding v. Roscenthal (I90I), I80 id. 43; Dunbar v. Dunbar (I90I), I80 id. I70; and Smith v. McQuillin (I906), I93 id. 289.

${ }^{25}$ Moch v. Market St. Bank (I900), I07 Fed. 897, 47 C. C. A. 49; In re $\mathrm{Ph}$. Semmer Glass Co. (Ig05), r35 Fed. 77, 67 C. C. A. 55r; Swarts v. Siegel (I902), II7 Fed. I3, 54 C. C. A. 399, which relies also on the provision in Section 57 i; In re Smith (1906), I46 Fed. 923; Cohen v. Pecharsky (1910), I2I N. Y. S. 602,67 Misc. 72.

${ }^{16}$ In re Dillon (Ig00), I0o Fed. 627; Hayer v. Comstock (Igor), II5 Ia. 187; In re Schmechel Cloak \& Suit Co. (1900), 104 Fed. 64; Smith v. Wheeler (I900), 66 N. Y. S. 780, 55 App. Div. I70. 
the former contention is perhaps debatable, but it seems clear that the proof provided for in Sec. $57^{\mathrm{i}}$ is of the claim of the creditor and not that of the surety: in other words, uncler this section the creditor proves his own claim; if the creditor fails to do so, the surety is allowed to prove it for him, and thus reduce the amount that the surety will have to pay the creditor ultimately. But the section nowhere gives the surety a right to prove a claim based on the obligation of the principal to reinburse the surety, and in case proof of the creditor's claim is made by the surety under Sec. 57i and Rule XXI (4), it is provided by the rule that "no dividend shall be paid upon such claim, except upon satisfactory proof that it will diminish pro tanto the original debt," thus indicating, apparently, the view of the Supreme Court that the claim proved under Sec. $57 \mathrm{i}$ is only the claim of the creditor.

It is obvious, therefore, that there is considerable difference of opinion as to the provability, under the present act, of contingent claims, and it may be of interest to review the decisions on the question of the surety's right against his bankrupt principal, as the question has come before the courts in various phases.

It is, of course, clear that if the surety, before the bankruptcy of the principal, has been compelled to pay the latter's debt, he has at the time of the filing of the bankruptcy petition a provable claim under Sec. 63a(I), being "a fixed liability, as evidenced by ... an instrument in writing, absolutely owing at the time of the filing of the petition," and the creditor, having been paid in full, has no claim against the bankrupt. If, however, the payment by the surety is made after the filing of the petition, but before the expiration of the time set for the filing of claims under Sec. $571{ }^{17}{ }^{17}$ a more difficult question is presented. If a debt is proved, is it the surety's debt, or is it the creclitor's debt, with the surety in the position of a payer entitled to subrogation under Sec. 57i?. In the case of In re Dillon ${ }^{18}$ it was held that the proof must still be made in the name of the creditor.

${ }^{17}$ With some exceptions, this time is one year from the adjudication.

${ }^{13}$ (1900), 100 Fed. 627. 
and that a claim filed under such circumstances in the name of the surety should be rejected. In the case of In re Heyman ${ }^{19}$ it was also held that under these circumstances the claim should be filed in the name of the creditor. ${ }^{20}$ But the ruling in these cases is merely technical, as the surety, having discharged the liability, is thereupon subrogated to the rights of the creditor under Sec. $57 \mathrm{i}$, and the result is therefore practically the same as in the case of payment by the surety before the principal's bankruptcy - the creditor has been paid his debt in full, and the surety has, in effect, received a dividend on the amount he has been compelled to pay. In such cases the surety's liability and right have become absolute during the bankruptcy proceedings, and it is clear that a correct result has been reached by following the provisions of the Act. Such cases are somewhat analogous to those upholding the provability of a claim against a bankrupt surety, maturing between the date of the petition and the expiration of the time for filing claims, ${ }^{21}$ but are even more clearly within the provisions of the statute.

The most difficult situations arise, however, when the courts have to consider the status of the surety who has not made any payment on account of his bankrupt principal's debt, and probably will not make any such payment during the bankruptcy proceedings, and possibly may never be called upon to make any such payment. This question has presented itself to the courts under varying circumstances and in various classes of cases, and the courts have come to various conclusions: the fundamental question in all these cases being "is the surety's claim provable?" and the answers to this question seeming to depend less upon the words of the statute than upon the circumstances under which the case arises. Typical questions which arise are: (I) may the surety be a petitioning creditor? (2) may he prove his

${ }^{19}$ (I899), 95 Fed. 800.

${ }^{20}$ In In re New (1902), I 6 Fed. 116 , proof was permitted in the name of the surety, but this was reversed in Livingstone v. Heineman (1903), 120 Fed. 786,57 C. C. A. 154. In Kahn v. Bledsoe (1908), 22 Okla. 666, it does not clearly appear that the proof was in the surety's name, but apparently it was. In In re Lyons Beet Sugar Refining Co. (I9I I), 192 Fed. 445 , the proof was also in the name of the surety.

${ }^{2}$ See cases cited under note 15 above. 
claim against the bankrupt? (3) is he capable of being preferred as a "creditor" under the statute? and (4) is his claim against his principal barred by the latter's discharge in bankruptcy?

\section{(I) May the Surety Be a Petitioning Creditor?}

The answer to this question clearly depends upon whether or not the surety's claim is a provable one under the provisions of the Act. Under Sec. $\mathrm{Ia}(9)$ a creditor is "anyone who owns a demand or claim provable in bankruptcy" and under Sec. 59b "three or more creditors who have provable claims .. . " may file a petition to have their debtor adjudged a bankrupt. Therefore if a claim is provable under Sec. 63 , its holder is entitleci to be a petitioning creditor.

This situation seems to have come squarely before the court for decision in only one case, ${ }^{22}$ in which the court, holding that sureties on notes given by the alleged bankrupt could not join in an involuntary petition against their principal, said:

"On each of the notes referred to, the debt or claim is that of the holder of the obligation to whom it is due, the surety having no direct interest in it, being only secondarily or contingently liable. He may pay the debt and become the holder, with all the rights incident thereto, but unless and until he does he occupies a secondary and subordinate position. The right to move is, in the first instance, lodged in the one who is actually possessed of the obligation of the debtor . . . the surety who has not taken up the obligation has no provable claim, and therefore has no standing to petition. It is not provided in the law that at that stage he can intervene, either in his own name or in the name of the creditor, and institute involuntary proceedings."

And it is difficult to see how the court could have come to a different conclusion without directly allowing a double proof. If a surety's claim is provable for the purpose of this section (Sec. $59 \mathrm{~b}$ ), a creditor and a surety or sureties could lump their claims and thus a note for $\$ 100$ secured by four indorsers could be the foundation of a petition against the maker, if he owed debts amounting to $\$ 1000$ : to carry the reasoning still further toward absurdity, a note for $\$$ roo secured by ten indorsers would

^s Phillips v. Dreher Shoe Co. (1902), II2 Fed. 404. 
alone render the maker amenable to involuntary bankruptcy, for any one of the indorsers may possibly have to pay the full amount of the note, and as it cannot be determined which one may become thus entitled to reimbursement by the maker, each ought to have a provable claim. It seems clear then that the court was right in deciding that the surety's claim is not "provable" so as to entitle him to be a petitioning creditor.

\section{(2) May the Surety Prove His Clatm Agarnst the Bank- RUPT PRINCIPAL?}

This question is really at the basis of all the decisions on the status of the surety's claim, and there is a large number of cases based on the premise that a surety is a "creditor," and therefore that he owns a demand or claim provable in bankruptcy. But only two cases have come to the writer's notice in which the court expressly passed upon the allowance of the claim of a surety who had not paid the principal's debt, and in both of these cases the claim was dismissed. In Insley v. Garside $^{23}$ the Circuit Court of Appeals for the Ninth Circuit expressly held that such a claim was not provable by the surety, but allowed the surety to prove the principal debt in the name of the creditor, under Sec. 57i. And in Dr. Voorhees Co. ${ }^{24}$ Judge Archbald upheld the referee's dismissal of a surety's.claim against the bankrupt principal on the authority of Phillips v. Dreher Shoe Co. ${ }^{25}$ decided by the same judge in 1902 . It may be that such claims have been admitted as "provable" debts in uncontested cases, but it seems unlikely, as even in the Heyman ${ }^{26}$ and Dillon ${ }^{27}$ cases, where the surety had actually paid the debt, it was held that the proof must nevertheless be made in the name of the creditor. The authorities, then, are evidently to the effect that a surety, who has not paid his principal's debt, does not have a provable claim, unless Sec. $57 \mathrm{i}$ is held to allow the proof of the surety's claim instead of the creditor's.

23 (1903), 121 Fed. 699,58 C. C. A. 119: order modified in 123 Fed. 78 , 59 C. C. A. 256.

${ }^{24}$ (I9II), I87 Fed. 611, 629, 633.

${ }^{2 \pi}$ (I902), II2 Fed. 404.

${ }^{2}$ In re Heyman (1899), 95 Fed. 800.

${ }^{2 \pi}$ In re Dillon (1900), I00 Fed. 627. 


\section{(3) May the Surety Be “Preferred" as His Principal's} CREDitor?

A preference is a judgment against, or a transfer by, an insolvent, the effect of such judgment or transfer being to enable one creditor to obtain a greater percentage of his debt than any other creditor;"28 we have seen that under Sec. Ia(9) a creditor is "anyone who owns a demand or claim provable in bankruptcy," the provability of claims being determined by Sec. 63 . It follows, then, that a person cannot be "preferred" under Sec. 6oa, unless he is a creditor, so if a surety is held to be capable of being preferred, it must be because his claim against his principal is a provable one.

The cases of preference which are of interest in this discussion, though all based upon the view that the surety is a creditor of his principal, are presented to the courts under several different sections of the statute, because of the various effects of a preference of a creditor. The sections noted below have called for interpretation as to whether or not a surety is included in them.

Sec. $3^{a(2)}$ providing that an insolvent's transfor of property to one or more creditors with intent to prefer such creditors over his other creditors, is an act of bankruptcy. In United States Surety Co. v. Iowa Manufacturing $\mathrm{Co}^{29}$ it was held that a payment by an insolvent principal to a surety on its bond was a payment to a "creditor" so as to subject the principal to involuntary bankruptcy proceedings.

Sec. 57 g, providing that the claims of creditors zoho have received certain kinds of preferences shall not be allowed unless such creditors surrender their preferences. The first manner in which a surety became subject to this section of the statute was by paying the debt after the creditor had received a preference, and then attempting to prove the claim in the name of the creditor under Sec. 57i. It was held early in the history of the bankruptcy act that under such circumstances the surety who had

2 Section $60 a$ of 1898 Act.

$=$ (1910), 179 Fed. 55 . 
paid the debt was only "subrogated to the right of the creditor" and that he therefore took the creditor's claim cum onere, and could not prove it without surrendering the preference received by the creditor. ${ }^{30}$ "The question also arose in cases where the bankrupt had given a note or check to the surety, who transferred it to a banker by whom payment was received from the bankrupt. It was held that the surety (the payee and indorser) was preferred by the payment to the banker, because his liability on the note or check was reduced, and therefore he could not prove any other claim he might have against the bankrupt unless he surrendered this preference paid to the banker. ${ }^{31}$

Sec. 6ob, providing that the trustee in bankruptcy may set aside and recover preferential judgments and transfers in cases where the person receiving (or benefited by) the preference had reasonable ground to believe that a preference was being effected. It has been held, with no dissent, that under this section a trustee in bankruptcy can recover a transfer made to a surety under the circumstances recited in the section, thus holding that a surety is a creditor with a provable claim. ${ }^{32}$

${ }^{30}$ In re Schmechel Cloak and Suit Co. (1900), I04 Fed. 64; Swarts v. Siegel (1902), I17 Fed. 13, 54 C. C. A. 399; Livingstone v. Heineman (1903), I20 Fed. 786, 57 C. C. A. I54 (reversing In re New, II6 Fed. II6). But the rule did not work both ways: a preference to an indorser will not prevent an indorsee bank from proving its claim. In re Wyly (1902), II6 Fed. 38; In re Levi (1903), 121 id. 198. In Doyle v. Milwaukee Nat. Bk. (I902), II6 Fied. 295,54 C. C. A. 97 , it was held that such a payment, under the facts in that case, was not a preference of the payee but this case has not been followed.

${ }^{31}$ In re Waterbury Furniture Co. (I902), II4 Fed. 255; In re Meyer (1902), II5 id. 997; In re Lyon (I903), I2I id. 723, 58 C. C. A. I43. To the contrary is In re Bullock (1902), II6 Fed. 667, which has not been followed. In Kahn v. Bledsoe (1908), 22 Okla. 666, a surety who had paid his principal's debt during the latter's bankruptcy was not allowed to prove his claim in that respect unless he surrendered a preference he had received in respect of another transaction.

\$2 Landry v. Andrews (I90I), 22 R. I. 597 ; Crandall v: Coats (I905), 133 Fed. 965 ; Kobusch v. Hand (1907), 156 Fed. 660, 84 C. C. A. 372; Chicago T. \& T. Co. v. Moody (1907), I38 IIl. App. 233 (affirmed 233 Ill. 634); In re Christopher Bailey \& Son (Ig09), I66 Fed. 982 ; Brown v. Streicher (I9I0), 177 Fed. 473; Stern v. Paper (r9io), 183 Fed. 228. In Chicago T. \& T. Co. v. Moody, supra, the court conceded that the surety did not have a provable claim, but held nevertheless that the transfer was voidable. In Reber v. Shulman (1910), 183 Fed. 564, a recovery by the trustee was denied on the ground that there was no showing that the surety, at the time of the preference, had reasonable ground to believe, \&c. In Bank of Wayne v. Gold (19II), I30 N. Y. S. 942, the court held void at the instance of a trustee in 
Most of these preference cases proceed upon the reasoning in Swarts v. Siegel, ${ }^{33}$ the leading case on the subject, which is cited as authority in practically all of the subsequent cases. In this case sureties had signed notes for the bankrupt, who had made payments on them while insolvent (these payments being preferences) and the sureties had paid the balance of the notes after the bankruptcy. The court held that the sureties could not prove their claim without returning the preferences paid to the holder of the notes. Judge Sanborn, who wrote the opinion in the Circuit Court of Appeals for the Eighth Circuit, reasoned as follows: a creditor is one who gives credit in business transactions, according to the Century Dictionary, and the sureties here, by lending their signatures to the maker of the notes, gave credit to it: the debt of a principal to his indorser or surety, before the latter has paid the obligation, is a contingent obligation founded on contract; and therefore provable under Sec. 63a(4): moreover, Sec. 57 i allows a surety to prove the creditor's claim against the bankrupt principal's estate. To sum up, "the accepted and customary definition of the term 'creditor,' its definition in the Act of I898, the clear terms and patent meaning of that act upon the subject under discussion, the better reasons and the greater weight of authority, all converge to establish and sustain the conclusion that an indorser, an accommodation maker, or a surety for a bankrupt is his creditor." It must be conceded that the great weight of authority agrees with this decision of Judge Sanborn, and it is clear, of course, that the result attained is desirable. A bankrupt ought not to be allowed to pay a note so as to take care of a surety any more than he ought to be allowed to pay a note to take care of the payee. But it seems at least doubtful if a surety is a "creditor" under the terms of the act, and clearly nobody but a "creditor" can

bankruptcy, a chattel mortgage given to a bank by the bankrupt to secure a loan which was used by the bankrupt to pay off notes on which a director of the bank was surety: the court held that as the surety was an officer of the bank, and as it appeared that the bank knew the purpose of the transaction, it was party to a preferential transfer under Section $60 \mathrm{~b}$, and could not claim under the chattel mortgage. Quuere: Could not the lien have been more simply set aside under Section $67 \mathrm{C}(\mathrm{r})$ ?

${ }^{33}$ (1902), II7 Fed. I3, 54 C. C. A. 399. 
be preferred under Sec. 6oa. The decisions in the preference cases cited above in which the sureties had paid the debt and were compelled, under Sec. $57 \mathrm{i}$, to become subrogated cum onere, are firmly enough based upon the clear meaning of the statute, but the other cases, which base the infirmity of the surety's claim upon the fact that he is a "creditor" who has been preferred, seem to be objectionable in reasoning, though not in result, and are clearly inconsistent with many decisions under this act.

(4) Is the Surety's Clatm Barred by the Principal's DisCHARGE IN BANKRUPTCY.

Under Sec. 17 a discharge in bankruptcy releases the bankrupt from all of his provable debts, with some exceptions not here important. If, therefore, a surety's claim against his principal is a provable debt of the latter, the principal is discharged from his liability, even though the surety does not have to make the payment on his principal's account until after the latter has been discharged in bankruptcy. To put concretely a typical case: $\mathrm{S}$ is a surety on B's note to $\mathrm{X}$, payable in two years; immediately after the making of the note, $B$ becomes bankrupt, $X$ proves his claim, or $\mathrm{S}$ proves it for him, and $\mathrm{X}$ receives, as do the other creditors, a dividend of 25 per cent., on the payment of which $B$ is discharged from all of his provable debts. After the discharge, $\mathrm{S}$ is compelled to pay $\mathrm{X}$ the remaining 75 per cent. of the amount of the note, and sues $B$ to recover the amount so paid. Was B's implied contract to reimburse $S$ a provable claim at the time of the filing of B's petition; or did this contract become effective only upon the payment by the surety of his principal's debt? If the former is the case, B's discharge is a bar to S's action; if the latter, it is not. And the cases under the present statute are apparently about evenly divided on this point. In Massachusetts two cases ${ }^{34}$ have held that the surety's claim was contingent at the date of the bankrupt's petition, and therefore was not provable and is not barred. And the Supreme Court

^ Goding v. Roscenthal (I90I), I80 Mass. 43; Smith v. McQuillin (1906), 193 id. 289. 
of New York (Appellate Term) has come to the same conclusion as to the claim of a retired partner who had been compelled, after the continuing partner's bankruptcy, to. pay a firm debt which the latter had agreed to pay. In the suit by the retired partner the other pleaded his discharge in bankruptcy; the court held ${ }^{35}$ that at the time of bankruptcy the retired partiner had no claim or existing debt against the other, that no claim arose until the other's failure to pay the firm debt (which he had agreed to pay) made it necessary for the retired partner to pay it, and that the discharge in bankruptcy was therefore ineffective as a bar.

On the other hand, the Supreme Court of New York (Appellate Division) held in an early case under the present statute $^{36}$ that the discharge in bankruptcy of a maker of a note was a bar to his indorser's action for reimbursement when the indorser had paid, after the maker's bankruptcy, a judgment on the note obtained against both maker and indorser before the maker's bankruptcy. The court cited Mace v. Wells, ${ }^{37}$ arising under the Act of $\mathrm{1} 84 \mathrm{I}$, and Hunt v. Taylor, ${ }^{38}$. arising under the Act of 1867 , and said, with reference to Sec. $57 \mathrm{i}$, that it was intended to accomplish the same effect as Sec. I9 of the Act of 1867 . The same result has been attained in two other cases. In Hayer v. Comstock, ${ }^{39}$ the Iowa Supreme Court held that a note-maker's discharge in bankruptcy was a bar to a surety's action based on his payment of the note several months after the maker's bankruptcy. The court held that the debt was a "fixed liability absolutely owing" at the date of the petition, regardless of the person to whom it was owing, thus confusing the liability of the debtor to his creditor with his liability to his surety (though the court says that it does not overlook the distinction between the two liabilities); and observed further that the plaintiff could have proved under Sec. 57i, thus again con-

as Ogilby v. Munro (1906), ror N. Y. Supp. 753, 52 Misc. r7o.

“ Smith v. Wheeler (I900), 66 N. Y. Supp. 780, 55 App. Div. I7o.

" (1849), 7 How. 272.

* (I87I), 108 Mass. 508.

* (I901), II5 Iowa, 187. 
fusing the two different liabilities. The reasoning of the Indiana Supreme Court in the case of Sweaney v. Baugher ${ }^{40}$ is even more unsatisfactory. - There $B$ conveyed land to $X$ subject to a mortgage, but $B$ agreed to pay off the mortgage before a date certain. Before this date arrived he became bankrupt, and scheduled as one of his liabilities his obligation to pay off the mortgage on X's land. (This is the only instance in all of these cases where it appears that any obligation to the surety was scheduled as a liability by the bankrupt.) After B's discharge, $\mathrm{X}$ paid the mortgage (though he had assumed no personal liability to pay it) and sued $B$ for reimbursement under the contract between them. B pleaded his discharge, and the court held that, as the debt was a fixed liability due to the mortgagee at the date of B's petition, and as X, being a surety, could have proved under Sec. $57 \mathrm{i}$, the debt was a provable claim and thus discharged.

It may be that the result attained by the rule laid down in the three cases last cited is desirable; it is doubtless the aim of a modern bankruptcy law to relieve the debtor of all of his obligations (with, of course, some obvious exceptions), and any rule that accomplishes this result is commendable on the ground of expediency. But it is submitted that the reasoning of these courts is hardly proof against criticism, and it would be infinitely better if the statute were so amended as to bring about this desirable result without too great a strain on the language of the act. And it must be remembered that the Supreme Court has not always been willing to permit even an admittedly desirable result to be brought about by a distortion of the provisions of the bankruptcy act. ${ }^{41}$

To sum up, the position of a surety who has not paid anything on account of his principal's debt is apparently as follows: he cannot petition to have his principal adjudicated bankrupt, because his claim is not provable; he cannot prove his claim in.

40 (I906), I66 Ind. 557.

4 As, for instance, in the case of York Mfg. Co. v. Cassell (I906), 201 U. S. 344, where the court's strict construction of the act, reversing the more desirable rule adopted in most of the circuits, produced an intolerable condition which led to the amendment of Section $47 a$. 
his principal's bankruptcy, for the same reason; yet he is (and has been since the inception of his contract of suretyship) a creditor having a provable claim, capable of being preferred by his principal, and subject to all the various effects of receiving a preference; and when, after his principal's bankruptcy, he has paid the latter's debt, he may or may not be able to recover from his principal, according to the jurisdiction in which suit must be brought.

Evans Holbrook.

University of Michigan. 